\title{
Modulation of $\mathrm{P} 2 \mathrm{X}_{7}$ receptor functions by polymyxin B: crucial role of the hydrophobic tail of the antibiotic molecule
}

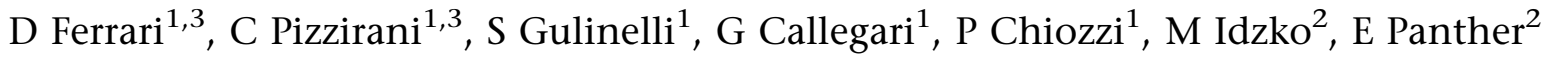 \\ and F Di Virgilio ${ }^{1}$
}

${ }^{1}$ Department of Experimental and Diagnostic Medicine, Section of General Pathology, and Interdisciplinary Center for the Study of Inflammation (ICSI), University of Ferrara, Ferrara, Italy and ${ }^{2}$ Department of Gastroenterology, University of Freiburg, Freiburg, Germany

Background and purpose: $\mathrm{P} 2 \mathrm{X}_{7}$ is a membrane receptor for extracellular ATP which is highly expressed in dendritic cells, macrophages and microglia where it mediates pro-inflammatory responses. The antibiotic polymyxin $B$, which binds to and neutralizes the toxic residue of bacterial lipopolysaccharide, greatly amplifies cellular responses mediated by the $\mathrm{P} 2 \mathrm{X}_{7}$ receptor. However, the molecular mechanism involved is so far unknown.

Experimental approach: We investigated the effects of polymyxin B and polymyxin B nonapeptide (PMBN) which is the deacylated amino derivative of polymyxin B lacking the $N$-terminal fatty amino acid 6-methylheptanoic/octanoic-Dab residue, in human macrophages and HEK293 cells stably expressing the human P2X ${ }_{7}$ receptor (HEK293-hP2 $\mathrm{X}_{7}$ ). Differences between the two antibiotics were assessed by monitoring the following: nucleotide-induced cytoplasmic free $\mathrm{Ca}^{2+}$ concentration changes, plasma membrane permeability changes, lactate dehydrogenase activity, cell morphology changes. Western blot and microscopic analyses of P2X ${ }_{7}$ GFP-expressing cells were also performed.

Key results: In contrast to polymyxin $B$, the polymyxin $B$ nonapeptide was unable to potentiate: a) the ATP-induced $C a^{2+}$ increase, b) pore formation and consequently ATP-mediated plasma membrane permeabilization; c) ATP-dependent cytotoxicity. Moreover, in contrast to polymyxin B, polymyxin B nonapeptide did not affect aggregation of the $\mathrm{P} 2 \mathrm{X}_{7}$ receptor subunits and it did not potentiate $\mathrm{P} 2 \mathrm{X}_{7}$-dependent cell fusion.

Conclusions and Implications: The effects of polymyxin B depended on the presence of its $N$-terminal fatty amino acid 6-methylheptanoic/octanoic-Dab residue as deletion of this residue abolished polymyxin B-dependent modulation of ATP-triggered responses. These findings are important in the search for allosteric modulators of the $\mathrm{P} 2 \mathrm{X}_{7}$ receptor.

British Journal of Pharmacology (2007) 150, 445-454. doi:10.1038/sj.bjp.0706994; published online 8 January 2007

Keywords: polymyxin B; extracellular ATP; P2 receptors; $\mathrm{P}_{2} \mathrm{X}_{7}$; endotoxin

Abbreviations: BzATP, 2', $3^{\prime}$-(4-benzoyl)-benzoyl-ATP; $\left[\mathrm{Ca}^{2+}\right]_{i}$ intracellular free $\mathrm{Ca}^{2+}$ concentration; Dab, 2,4-diaminobutyric acid residue; DFP, di-isopropyl fluorophosphate; wtHEK293, wild-type human embryonic kidney 293 cells; HEK293-hP2X 7, HEK293 cells stably expressing the human P2X 7 receptor; HEK293-rP2X 7, HEK293 cells stably expressing the rat $\mathrm{P} 2 \mathrm{X}_{7}$ receptor; $\mathrm{LDH}$, lactate dehydrogenase; LPS, lipopolysaccharide; oATP, oxidized ATP; PMBN, polymyxin B nonapeptide; PMSF, phenylmethylsulphonylfluoride; SNPs, single nucleotide polymorphisms

\section{Introduction}

Receptors for extracellular nucleotides (P2 receptors) are expressed by virtually all cell types (Dubyak and ElMoatassim, 1993; Di Virgilio et al., 2001; Burnstock, 2004), making them very attractive targets for the pharmacological

Correspondence: Dr D Ferrari, Department of Experimental and Diagnostic Medicine, Section of General Pathology, and Interdisciplinary Center for the Study of Inflammation (ICSI), University of Ferrara, I-44100 Ferrara, Italy. E-mail: dfr@unife.it

${ }^{3}$ These authors contributed equally to this work.

Received 1 August 2006; revised 13 September 2006; accepted 18 September 2006; published online 8 January 2007 modulation of physiological or pathological responses (Jacobson et al., 2002). According to their molecular structure, P2 receptors are divided into two subfamilies: metabotropic P2Y receptors and ionotropic P2X receptors (Fredholm et al., 1997). Eight P2Y and seven P2X receptor subtypes have been cloned so far. P2Y receptors are G-protein-coupled, seven-membrane-spanning proteins with the amino-terminal domain facing the extracellular environment, and the carboxyl-terminal domain on the cytoplasmic side of the plasma membrane. Signal transduction occurs via activation of phospholipase $\mathrm{C}$ and/or 
stimulation/inhibition of adenylate cyclase (von Kugelgen and Wetter, 2000).

P2X receptors are ligand-gated ion channels activated by extracellular ATP and selective for monovalent and divalent cations (North, 2002). The amino- and carboxyl-terminal domains are both cytoplasmic. Seven different monomers have been cloned so far and named $\mathrm{P}_{2} \mathrm{X}_{1-7}$ receptors. Homoor in some cases hetero-polymerization of the different subunits has been described.

The cationic antibiotic polymyxin B is a mixture of cyclic decapeptide derivatives originally isolated from strains of Bacillus polymyxa. The basic structure of the molecule consists of a peptide ring and a fatty acid residue linked by an amide bond (Storm et al., 1977). These two domains confer amphipatic properties to the antibiotic that shares with colistin, another peptidic antibiotic, the presence of 2,4-diaminobutyric acid residues (Dab), conferring five positive charges to the molecule. Polymyxin $\mathrm{B}$ has a high affinity for lipid $A$, the toxic portion of the bacterial endotoxin (lipopolysaccharide, LPS). Polymyxin B is very active in causing permeabilization and killing of Gramnegative bacteria, being bactericidal even to multidrugresistant Gram-negative cells (Storm et al., 1977; Vaara and Viljanen, 1985; Evans et al., 1999; Daugelavicius et al., 2000). Cytotoxic activity of Polymyxin B is not restricted to bacteria, but extends also to yeasts and protozoa (Storm et al., 1977; Evans et al., 1999).

Cationic peptides in addition to their ability to kill microbes can modulate effector functions in innate immunity and upregulate gene expression in eukaryotic cells (Hancock, 2001). For example, polymyxin B upregulates expression of co-stimulatory CD86 antigen and HLA class I and II molecules, and increases dendritic cell responses (Marshall et al., 2004; Valentinis et al., 2005). Dendritic cells, macrophages and microglia express at high level the $\mathrm{P}_{2} \mathrm{X}_{7}$ receptor subtype (Di Virgilio et al., 2001). In these cells $\mathrm{P}_{7}$ receptor mediates transmembrane ion fluxes, reversible plasma membrane permeabilization and IL-1 $\beta$ release (Ferrari et al., 2000). Membrane permeabilization and cytokine release depend on the pore-forming activity endowed in the extended cytoplasmic $\mathrm{COOH}$ tail of the receptor. The $\mathrm{P}_{2} \mathrm{X}_{7}$ receptor is highly polymorphic. A few of the single nucleotide polymorphisms (SNPs) identified have been investigated in detail, unveiling single base substitutions that cause loss or gain of function, or faulty intracellular sorting (Gu et al., 2001; Cabrini et al., 2005).

We recently reported that polymyxin $\mathrm{B}$ modulates responses elicited by $\mathrm{P}_{2} \mathrm{X}_{7}$ receptor in cells expressing the native or recombinant $\mathrm{P}_{2} \mathrm{X}_{7}$ receptor (Ferrari et al., 2004). Although our data suggested a direct interaction between polymyxin $\mathrm{B}$ and the $\mathrm{P}_{2} \mathrm{X}_{7}$ receptor, no mechanistic information was available. To shed light on the molecular basis of polymyxin $\mathrm{B}-\mathrm{P}_{2} \mathrm{X}_{7}$ receptor interaction, we took advantage of a deacylated amino derivative of polymyxin $\mathrm{B}$, the polymyxin $\mathrm{B}$ nonapeptide (PMBN) generated by removing the $N$-terminal fatty amino-acid 6-methylheptanoic/ octanoic-Dab. PMBN shares with polymyxin B the ability to permeabilize the outer membrane of Gram-negative bacteria and to neutralize the toxic effects of LPS but has a reduced toxicity in eukaryotic cells (Duwe et al., 1986; Tsubery et al., 2000, 2001, 2002).

In this study, we investigated the effect of PMBN in HEK293 cells stably expressing the human $\mathrm{P}_{2} \mathrm{X}_{7}$ receptor (HEK293-hP2X 7 ). Our data show that PMBN has a strikingly reduced ability to modulate $\mathrm{P}_{2} \mathrm{X}_{7}$ receptor-mediated responses and suggest that the lipophilic $N$-terminal fatty amino-acid 6-methylheptanoic/octanoic-Dab is crucial for interaction with the $\mathrm{P} 2 \mathrm{X}_{7}$ receptor.

\section{Methods}

\section{Cells and solutions}

$\mathrm{HEK}_{293-\mathrm{hP}_{2}}$ cells were cultured in DMEM-F12 (SigmaAldrich, Milan, Italy) complemented with $10 \%$ heat-inactivated FBS, $100 \mathrm{U} \mathrm{ml}^{-1}$ penicillin and $100 \mu \mathrm{g} \mathrm{ml}^{-1}$ streptomycin (all from Life Technologies, Milan, Italy). Human macrophages were obtained from circulating monocytes (buffy coats kindly prepared by Banca del Sangue, Arcispedale S Anna, Ferrara, Italy) by one-step gradient (Ficoll, Pharmacia Biotech Spa, Cologno Monzese, Italy). After separation, mononuclear cells were rinsed in PBS and resuspended in RPMI 1640 medium containing 5\% human serum, 2\% glutamine, and plated onto polylysine-coated flasks. Adherent cells (monocytes) were detached and allowed to differentiate into macrophages for 5 days. Fluorescence measurements and lactic dehydrogenase $(\mathrm{LDH})$ release were performed in a saline solution containing $125 \mathrm{mM} \mathrm{NaCl}, 5 \mathrm{mM} \mathrm{KCl}, 1 \mathrm{mM} \mathrm{MgSO}_{4}$ $1 \mathrm{mM} \mathrm{Na}_{2} \mathrm{HPO}_{4}, 5.5 \mathrm{~mm}$ glucose, $5 \mathrm{mM} \mathrm{NaHCO} 3,1 \mathrm{mM} \mathrm{CaCl}_{2}$ and $20 \mathrm{mM}$ HEPES (pH 7.4 with $\mathrm{NaOH}$ ), hereafter also referred to as standard saline solution. For some experiments cells were incubated in a low-salt solution containing $300 \mathrm{~mm}$ sucrose, $1 \mathrm{mM} \mathrm{KH} \mathrm{KPO}_{4}, 5.5 \mathrm{mM}$ glucose, $1 \mathrm{mM} \mathrm{CaCl}_{2}$, and $20 \mathrm{mM}$ HEPES, pH 7.4 with KOH. Polymyxin B and PMBN were used at a concentration of $10 \mu \mathrm{g} \mathrm{ml}^{-1}$ throughout, unless otherwise indicated.

\section{Cytoplasmic-free $\mathrm{Ca}^{2+}$ measurements}

Changes in the intracellular free $\mathrm{Ca}^{2+}$ concentration $\left(\left[\mathrm{Ca}^{2+}\right]_{i}\right)$ were measured with the fluorescent indicator fura-2/AM, using an LS50 Perkin Elmer fluorometer (Perkin Elmer Ltd., Beaconsfield, UK). For fura-2/AM loading, cells $\left(1 \times 10^{7} \mathrm{ml}^{-1}\right)$ were resuspended in standard saline solution, in the presence of $4 \mu \mathrm{M}$ fura-2/AM and $250 \mu \mathrm{M}$ sulfinpyrazone (Sigma-Aldrich). Incubation was performed at $37^{\circ} \mathrm{C}$ for $20 \mathrm{~min}$. Cells were then washed in the same solution and $\left[\mathrm{Ca}^{2+}\right]_{i}$ changes were determined in a thermostatted, magnetically stirred cuvette, with the 340/380 excitation ratio at an emission wavelength of $505 \mathrm{~nm}$. In some experiments, $\left[\mathrm{Ca}^{2+}\right]_{i}$ changes are reported as $\left[\mathrm{Ca}^{2+}\right]_{i}$ increases over basal values $\left.\left(\Delta \mathrm{Ca}^{2+}\right]_{i}\right)$.

\section{Changes in plasma membrane permeability}

ATP-dependent increases in plasma membrane permeability were measured by monitoring the uptake of the dye ethidium bromide. Briefly, $5 \times 10^{5}$ cells $\mathrm{ml}^{-1}$ were kept in a magnetically stirred fluorometric cuvette, thermostatted at 
$37^{\circ} \mathrm{C}$ and incubated in the presence of $20 \mu \mathrm{M}$ ethidium bromide. To achieve complete permeabilization of the cells, $100 \mu \mathrm{M}$ digitonin was added at the end of the experiment (100\% fluorescence signal). Fluorescence was measured at an excitation/emission wavelength couple of $360 / 580 \mathrm{~nm}$.

\section{Changes in cell morphology}

HEK293-hP2X 7 cells were plated in six-well plates at 50\% confluence, rinsed with standard saline solution and then incubated for different times in the same saline containing ATP or 2',3'-(4-benzoyl)-benzoyl-ATP (BzATP), in the presence or absence of polymyxin $B$ or its analogue PMBN. Control cells were incubated in standard saline in the absence of stimuli. Phase contrast pictures were taken with an inverted microscope (Olympus IMT-2, Olympus Optical Co, Ltd., Tokyo, Japan) equipped with an OM-4 Ti OLYMPUS camera.

\section{Western blots}

HEK293-hP2X 7 cells were plated in Petri dishes and stimulated in RPMI 1640 at $80 \%$ of confluence. Cells were maintained in the presence or absence of polymyxin $B$ or PMBN for $15 \mathrm{~min}$. BzATP $(100 \mu \mathrm{M})$ or ATP $(1 \mathrm{mM})$ were then added and cells were incubated for further $30 \mathrm{~min}$. Medium was then removed, cells were incubated in sucrose-saline solution containing benzamidine, phenylmethylsulphonylfluoride (PMSF) and di-isopropyl fluorophosphates (DFP) and shaken on ice for $15 \mathrm{~min}$. Finally, cells were detached from dishes in the same sucrose-saline solution and centrifuged at $112 \mathrm{~g}$ for $5 \mathrm{~min}$. The pellets were resuspended in sucrose saline containing benzamidine and PMSF and kept at $-80^{\circ} \mathrm{C}$. A $7.5 \%$ acrilamide gel was run by loading in each lane $70 \mu \mathrm{g}$ of protein solubilized in O solution $(10 \% \mathrm{w} / \mathrm{v}$ glycerol, $5 \% \mathrm{v} / \mathrm{v} 2$-mercaptoethanol, $2.3 \% \mathrm{w} / \mathrm{v}$ SDS, $62.5 \mathrm{mM}$ Tris-Cl, $0.003 \%$ bromophenol blue). Western blotting was performed by transferring proteins onto a nitrocellulose membrane (Amersham Biosciences, Little Chalfont, UK). Blocking of non-specific binding sites was achieved by incubating the membrane with $10 \%$ skim-milk in TBS buffer (10 mM Tris-Cl, $150 \mathrm{~mm} \mathrm{NaCl}, \mathrm{pH} 8.0$ ) for $1 \mathrm{~h}$. The primary anti-P2X $\mathrm{X}_{7}$ antibody (Sigma-Aldrich, Milano, Italy) was used overnight at a dilution of 1:200 in TBS buffer containing 2\% BSA. Antibody binding was visualized by the protein A peroxidase-linked process (Amersham Biosciences, Little Chalfont, UK).

\section{Microscopic analyses of GFP-expressing cells}

Cells layered on $40 \mathrm{~mm}$ round coverslips were placed in a thermostatted Leyden chamber (model TC-202A, Medical Systems Corp., NY, USA) on the stage of an inverted Nikon Eclipse TE300 microscope (Nikon, Tokyo, Japan) equipped with epifluorescence and a piezoelectric motorization of the objective (Physik Instrumente, GmbH and Co., Karlsruhe/ Palmbach, Germany). Bright field or fluorescence images were captured with a back-illuminated CCD camera (Princenton Instruments, Trenton, NJ, USA), and analysed with the Metamorph software (Universal Imaging Corporation, West Chester, PA, USA).

Measurement of lactate dehydrogenase activity Cells $\left(1.5 \times 10^{5} \mathrm{ml}^{-1}\right)$ were plated in 24 -well plates. After $24 \mathrm{~h}$, cells were rinsed and incubated in standard saline solution. ATP was then added in the presence or absence of polymyxin B or PMBN. Supernatants were collected, cleared by centrifugation $(10 \mathrm{~min}$ at $250 \mathrm{~g})$, transferred to $1.5 \mathrm{ml}$ vials and stored at $-80^{\circ} \mathrm{C}$. For measurement of activity, supernatants were thawed and added to a solution containing $0.63 \mathrm{mM}$ pyruvate, $11.3 \mathrm{mM} \mathrm{NADH}, 44.4 \mathrm{mM} \mathrm{K}_{2} \mathrm{HPO}_{4}$, $16.8 \mathrm{mM} \mathrm{KH}_{2} \mathrm{PO}_{4}(\mathrm{pH} 7.5)$. Absorbance $(340 \mathrm{~nm})$ was measured in a spectrofluorometer (Ultrospec 3000, Pharmacia Biotech, Milan, Italy). Lysis of samples with $0.1 \%$ Triton $\mathrm{X}-100$ provided the total $\mathrm{LDH}$ cell content (100\% LDH release).

\section{Statistical analyses}

Data are expressed as mean \pm s.d. For analysis of a significant difference between means, Student's $t$-test was used.

\section{Reagents}

ATP was from Roche Diagnostics (Monza, Italy). Polymyxin B, PMBN, oxidized ATP (oATP), BzATP, ethidium bromide, digitonin, ionomycin, DFP, benzamidine and PMSF were from Sigma Aldrich (Milan, Italy). KN-62 was from Calbiochem (Calbiochem-Novabiochem Corporation, La Jolla, CA, USA). Fura-2/AM was from Molecular Probes (Leiden, The Netherlands).

\section{Results}

Effect of PMBN on $\mathrm{P}_{2} \mathrm{X}_{7}$ receptor-dependent $\left[\mathrm{Ca}^{2+}\right]_{\mathrm{i}}$ rise and pore formation

Figure 1a shows that ATP-stimulated HEK293-hP2X 7 cells underwent a transient $\left[\mathrm{Ca}^{2+}\right]_{i}$ rise followed by a slow decrease (continuous line). Pre-incubation (3 min) with polymyxin $\mathrm{B}$ potentiated the $\mathrm{Ca}^{2+}$ response elicited by ATP. PMBN on the other hand had no effect. Moreover, when added together with polymyxin B, PMBN was unable to prevent polymyxin B-mediated effects. Values of the $\Delta \mathrm{Ca}^{2+}$ increases (8 min after ATP addition) were as follows: ATP, $318 \pm 38.2 \mathrm{nM}$; ATP + PMBN, $320 \pm 34.7 \mathrm{nM}$; ATP + polymyxin $\mathrm{B}, 736.5 \pm 54.5 \mathrm{nM}$; for ATP vs ATP $+\mathrm{PMBN}, P=N S(n=3)$; for ATP vs. ATP + polymyxin B, $P<0.05(n=3)$.

The lack of effect of PMBN was not dependent on the concentration of the antibiotic or nucleotide used. The nonapeptide did not modify ATP-mediated responses even when the nucleotide was used at a concentration of $3 \mathrm{~mm}$ (not shown). Similarly, the ATP response did not change when cells were incubated in the presence of different PMBN concentrations (from $1 \mathrm{ng} \mathrm{ml}^{-1}$ to $1 \mu \mathrm{g} \mathrm{ml}^{-1}$ ), (data not shown). On the contrary, PMBN slightly but significantly potentiated the $\left[\mathrm{Ca}^{2+}\right]_{i}$ rise stimulated by the more potent $\mathrm{P}_{2} \mathrm{X}_{7}$ receptor agonist BzATP, though it was much less potent than polymyxin B (Figure $1 \mathrm{~b}$ ); Values of the $\Delta \mathrm{Ca}^{2+}$ increases 

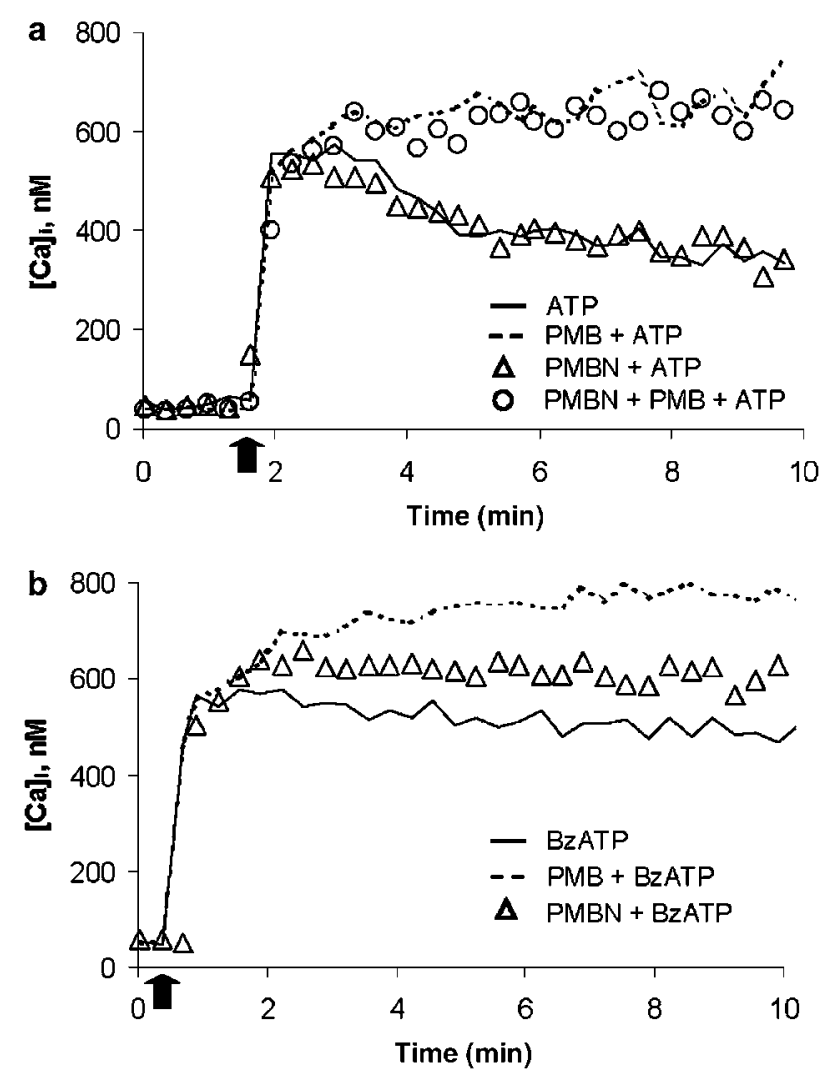

Figure 1 PMBN does not alter the ATP-induced increase in $\left[\mathrm{Ca}^{2+}\right]_{i}$. HEK293-hP2X 7 cells $\left(1 \times 10^{6} \mathrm{ml}^{-1}\right)$ were loaded with the fluorescent dye fura-2/AM as reported in Methods. In (a), Cells were then incubated at $37^{\circ} \mathrm{C}$ in standard saline solution and challenged with $1 \mathrm{mM}$ ATP. Polymyxin B or PMBN were added 3 min before ATP. In a separate experiment polymyxin $B$ and $P M B N$ were added together prior to ATP addition. In (b), cells were pre-incubated with polymyxin B or PMBN and challenged with $300 \mu \mathrm{M}$ BzATP; Arrow indicates addition of the nucleotide. A representative experiment is shown $(n=3)$.

were as follows: BzATP, $478 \pm 33.5 \mathrm{nM}$; BzATP + PMBN, $577 \pm 34 \mathrm{nM}$; BzATP + polymyxin B, $741 \pm 26.4 \mathrm{nM}$; for BzATP vs BzATP + PMBN, $P<0.005, \quad(n=3) ; \quad$ for BzATP $\quad$ vs $\mathrm{BzATP}+$ polymyxin $\mathrm{B}, P<0.05(n=3)$.

Opening of the $\mathrm{P}_{2} \mathrm{X}_{7}$ receptor pore allows the influx of low molecular mass solutes from the extracellular space into the cytoplasm (Steinberg et al., 1987). Pore formation can be monitored by measuring trapping of cell impermeant fluorescent molecules such as ethidium bromide (molecular mass $314 \mathrm{Da}$ ). As previously shown by Ferrari et al. (2004), during a $15 \mathrm{~min}$ incubation, $1 \mathrm{mM}$ ATP caused a small ethidium bromide uptake (between 5 and $10 \%$ of total uptake caused by digitonin) that was strongly potentiated by polymyxin B (compare dashed and continuous line, Figure 2a). On the contrary, PMBN had no effect on ethidium bromide uptake, even when tested in the presence of $3 \mathrm{mM}$ ATP (not shown). Figure 2b shows that PMBN slightly potentiated BzATP-stimulated ethidium uptake, although to a much lesser extent than polymyxin $\mathrm{B}$. In the presence of $\mathrm{KN}-62$, a potent competitive $\mathrm{P}_{2} \mathrm{X}_{7}$ receptor blocker, ethidium bromide uptake stimulated by BzATP was abolished (Figure 2c). Polymyxin B, but not PMBN, reversed the blocking effect of $\mathrm{KN}-62$.
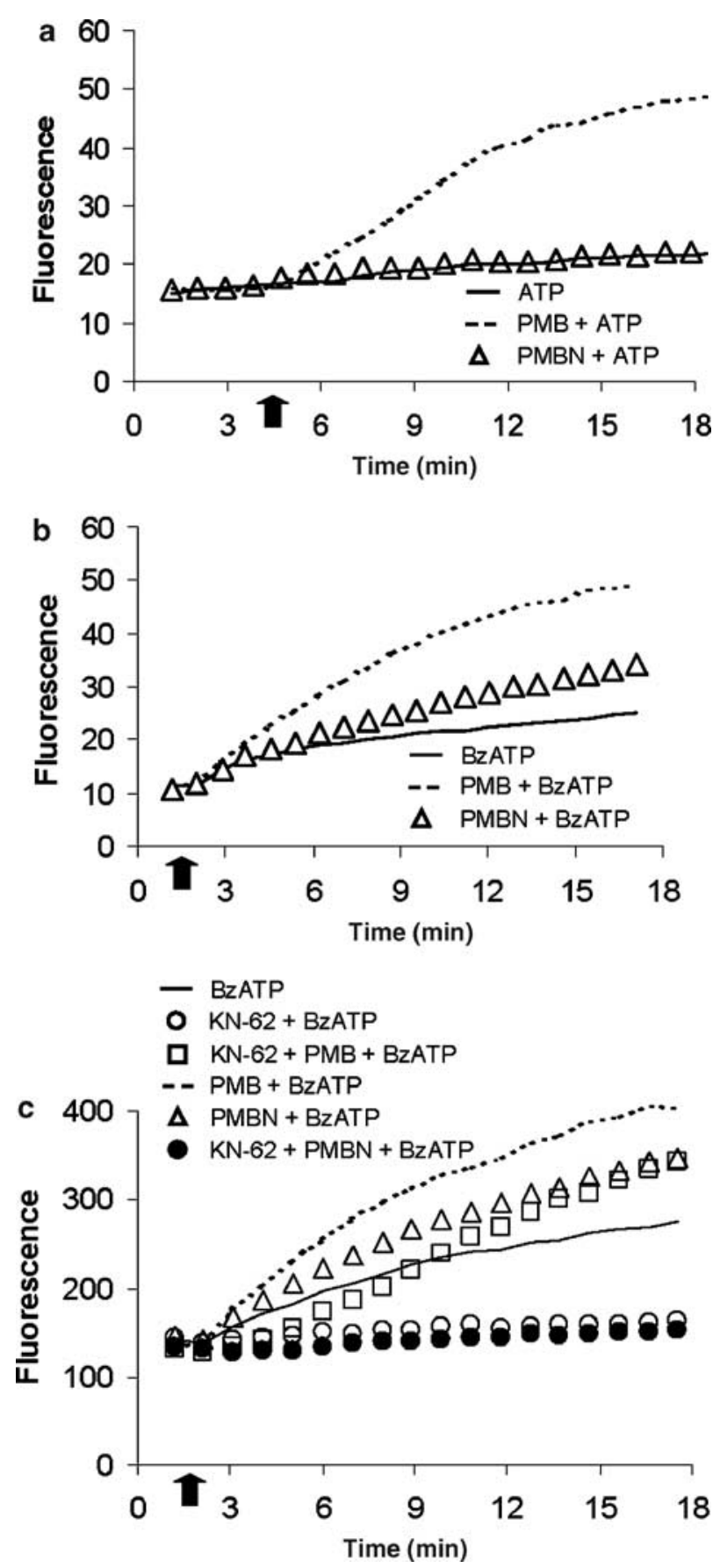

Figure 2 Effects of PMBN on ethidium bromide uptake induced by ATP or by BzATP. In (a), PMBN did not potentiate ATP-induced ethidium bromide uptake. HEK293-hP2X 7 cells $\left(5 \times 10^{5} \mathrm{ml}^{-1}\right)$ were incubated at $37^{\circ} \mathrm{C}$, in a standard saline solution containing $20 \mu \mathrm{M}$ ethidium bromide and then challenged with 1 mM ATP. Polymyxin B or PMBN were added $3 \mathrm{~min}$ before ATP stimulation. In (b), PMBN increased BzATP-induced ethidium bromide uptake. Cells were incubated as in (a) and challenged with $300 \mu \mathrm{M}$ BzATP. Cells were also pre-incubated with polymyxin $\mathrm{B}$ or PMBN and then challenged with BzATP. In (c), KN-62 (100 $\mu \mathrm{M})$ inhibited PMBN-induced ethidium bromide uptake due to stimulation with BzATP. Arrow indicates addition of the nucleotide. A representative experiment is shown $(n=5)$. 
Effect of PMBN on $\mathrm{P}_{2} \mathrm{X}_{7}$ receptor-dependent cytotoxicity Prolonged activation of the $\mathrm{P}_{2} \mathrm{X}_{7}$ receptor triggers a dramatic perturbation of the intracellular ion homeostasis leading to morphological changes and cell death (Di Virgilio et al., 1998). Polymyxin B and PMBN per se were devoid of toxic effects after incubation for up to $6 \mathrm{~h}$ (Figure 3c and e). Upon incubation with ATP (Figure 3b), cells underwent the usual morphological alterations caused by this nucleotide in $\mathrm{P}_{2} \mathrm{X}_{7}$ receptor-expressing cells, that is swelling, retraction of filaments and rounding. Polymyxin B, but not PMBN, greatly enhanced ATP-triggered morphological changes
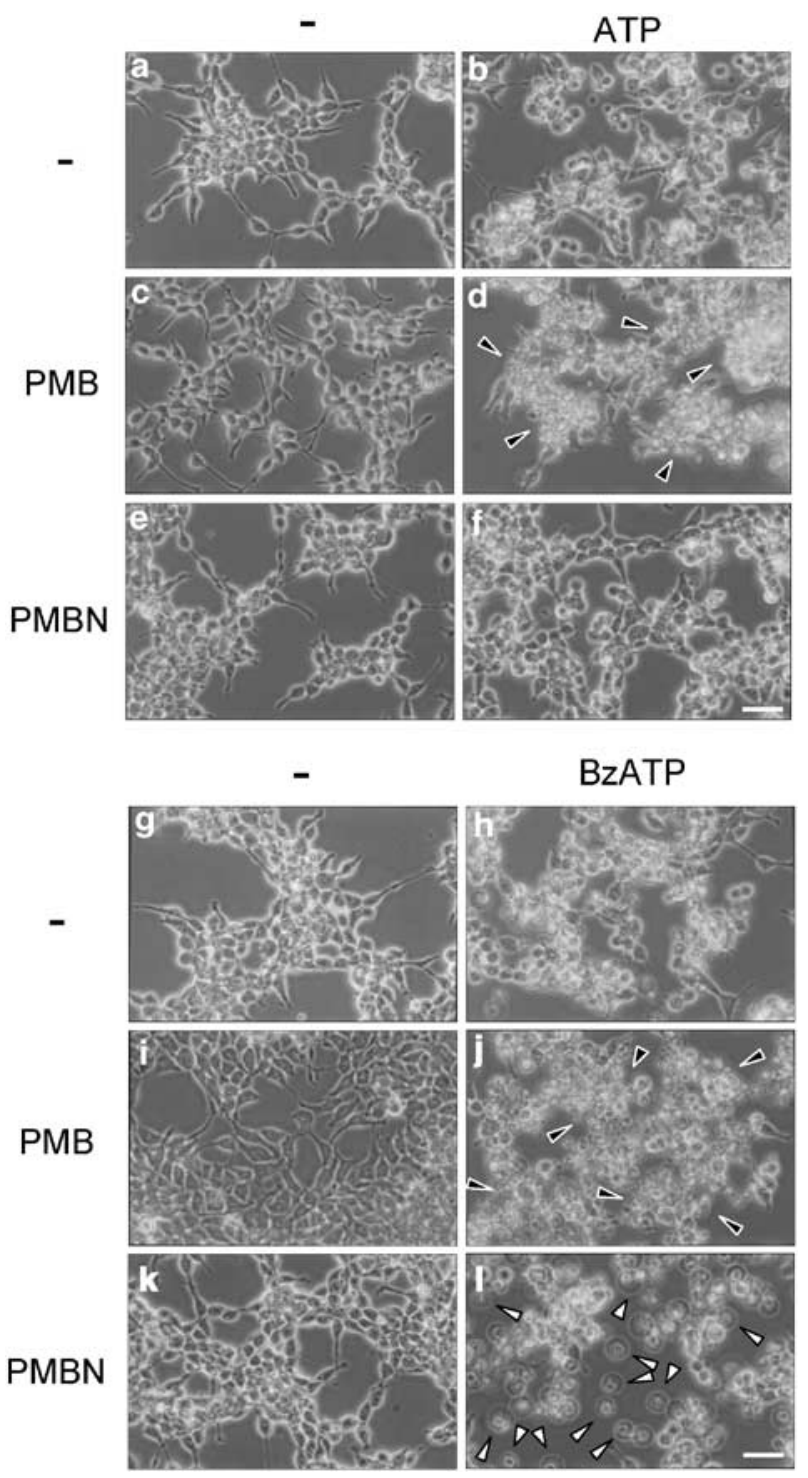

Figure 3 Polymyxin $\mathrm{B}$, but not $\mathrm{PMBN}$, induced morphological changes in HEK293-hP2X 7 cells upon stimulation with ATP. HEK293$\mathrm{hP} 2 \mathrm{X}_{7}$ cells $\left(50 \%\right.$ confluence) were incubated for $6 \mathrm{~h}$ at $37^{\circ} \mathrm{C}$, in standard saline solution, with $\mathrm{PMBN}$ or polymyxin $\mathrm{B}$, in the presence or absence of $1 \mathrm{mM}$ ATP or $300 \mu \mathrm{M}$ BzATP. Photographs were taken with a $\times 40$ objective. (a) Controls; (b) ATP; (c) polymyxin B; (d) polymyxin B + ATP; (e) PMBN; (f) PMBN + ATP; (g) controls; (h) BzATP; (i) polymyxin B; (j) polymyxin B + BzATP; (k) PMBN; (l) $\mathrm{PMBN}+\mathrm{BzATP}$. Black arrowheads, clumped cells. White arrowheads, swollen cells. Bars, $50 \mu \mathrm{M}$. A representative experiment is shown, $(n=6)$. causing extensive cell shrinkage and clumping (arrowheads) in addition to swelling and rounding (compare Figures 3d and f). Not surprisingly, BzATP caused more widespread morphological alterations than ATP (Figure 3h, that were further enhanced by the presence of polymyxin B (Figure $3 \mathrm{j}$, black arrowheads). As already observed for plasma membrane permeabilization, the effect of BzATP on cell morphology was enhanced in the presence of PMBN: cells did not only show rounding, clumping and filament retraction, but also became swollen and phase-lucent (Figure 31, white arrowheads).

To check whether morphological changes were paralleled by an irreversible damage of the plasma membrane leading

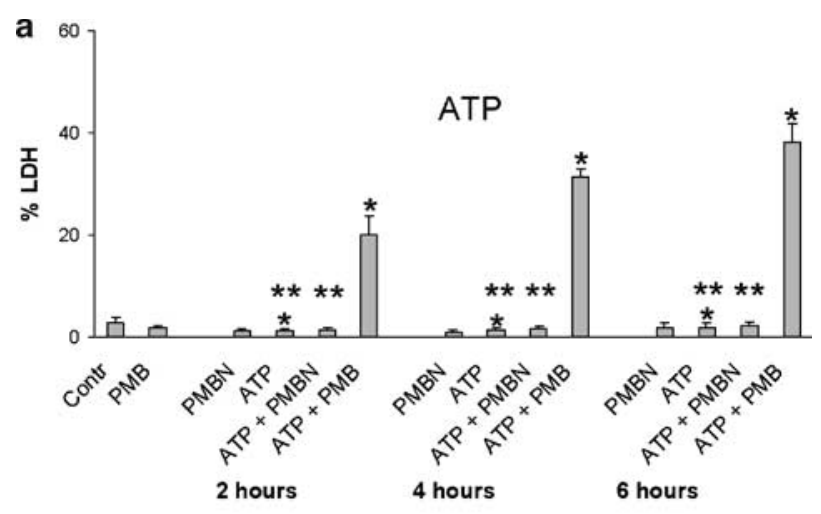

b
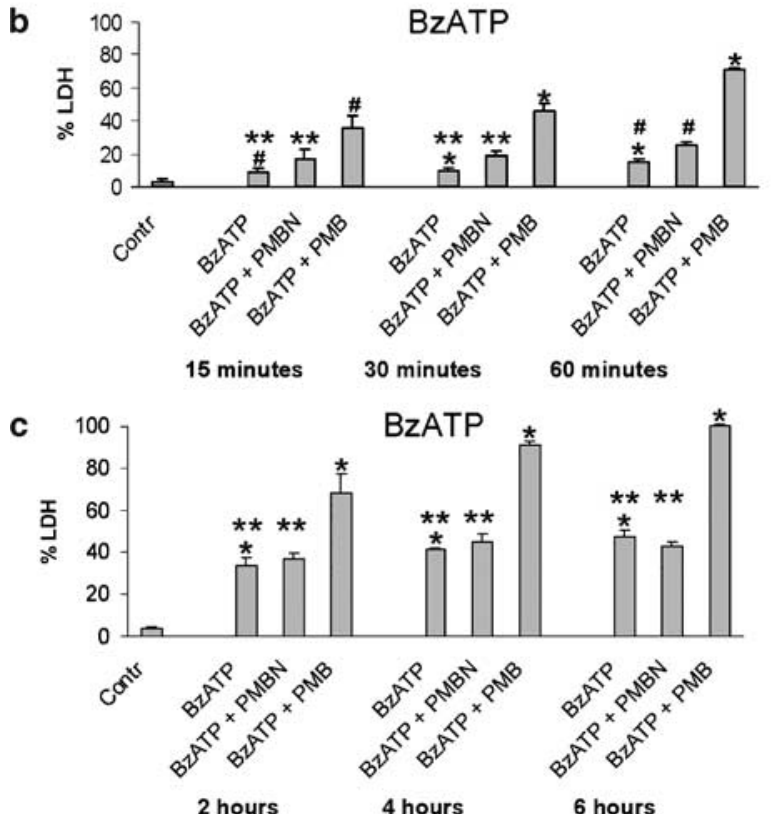

Figure 4 PMBN did not increase ATP- or BzATP-induced cell death, as measured by LDH release. HEK293-hP2X 7 cells $\left(3 \times 10^{5} \mathrm{ml}^{-1}\right)$ were incubated for different times at $37^{\circ} \mathrm{C}$, in a standard saline solution containing $600 \mu \mathrm{M} \mathrm{ATP}$, in the presence or absence of $\mathrm{PMBN}$ or polymyxin $\mathrm{B}(\mathbf{a}) ;(\mathbf{b})$ and (c), cells were treated as in (a) and then challenged with $300 \mu \mathrm{M}$ BzATP instead of ATP. At the end of the incubation, supernatants were collected, and analysed for LDH content as specified in Methods. Supernatants of control cells were collected at $6 \mathrm{~h}$. $\mathrm{LDH}$ release is expressed as a percentage of the total cellular LDH content obtained by lysing cells with $0.1 \%$ Triton $X$ 100. Data are means \pm s.d. of triplicate determinations from three independent experiments. ${ }^{*}=P<0.001 ;{ }^{*}=N S ; \#=P<0.05$. 
to necrotic cell death, we measured release of the cytosolic enzyme LDH. Figure $4 \mathrm{a}$ shows that $1 \mathrm{mM}$ ATP did not increase LDH release above control levels in the HEK293$\mathrm{hP}_{2} \mathrm{X}_{7}$ cells. The concomitant presence of polymyxin $\mathrm{B}$, but not PMBN, caused a time-dependent release of $\mathrm{LDH}$ that, after $6 \mathrm{~h}$, reached $40 \%$ of total cellular LDH content. BzATP, at a concentration of $300 \mu \mathrm{M}$, increased LDH release after an incubation time as short as $30 \mathrm{~min}$ (Figure $4 \mathrm{~b}$ ), to reach a peak release of $40 \% \mathrm{LDH}$ after $6 \mathrm{~h}$ (Figure $4 \mathrm{c}$ ). The PMBN potentiating effect on BzATP-induced LDH release was statistically significant only at the $60 \mathrm{~min}$ time point $(P<0.05$ for BzATP vs BzATP + PMBN, see Figure $4 \mathrm{~b})$, while polymyxin B potentiated ATP- and BzATP-stimulated LDH release at all time points tested (see Figure $4 \mathrm{a}-\mathrm{c}$ ).

Polymyxin B but not PMBN increases ATP- or BzATP-induced cytotoxicity in cells expressing the native $P 2 X_{7}$ receptor

Human macrophages express the $\mathrm{P}_{2} \mathrm{X}_{7}$ receptor at high levels (Falzoni et al., 1995) and we therefore chose these cells to check whether polymyxin $\mathrm{B}$ and PMBN had a different effect on the native $\mathrm{P}_{2} \mathrm{X}_{7}$ receptor. Polymyxin $\mathrm{B}$ or PMBN were per se non-cytotoxic for macrophages (Figures $5 \mathrm{c}$ and e), while incubation of cells with ATP (Figure $5 \mathrm{~b}$ ) induced cell shrinkage and death that was increased in the presence of polymyxin B, but not PMBN (compare Figures $5 \mathrm{~d}$ and $\mathrm{f}$ ). Alterations in cell morphology caused by BzATP were also enhanced by polymyxin B, but not by PMBN (compare Figures $5 \mathrm{j}$ and 51).

\section{Polymyxin B but not PMBN increases $P 2 X_{7}$ receptor oligomerization}

The molecular basis of the transition from channel to pore in $\mathrm{P}_{2} \mathrm{X}_{7}$ receptors is poorly understood. It has been suggested that the $\mathrm{P}_{2} \mathrm{X}_{7}$ pore may increase or decrease in size by subunit addition or subtraction, respectively (Tatham and Lindau, 1990). Surprenant and co-workers were unable to detect multisubunit $\mathrm{P}_{2} \mathrm{X}_{7}$ receptor aggregations in lysates from rat brain, but easily detected multimeric complexes in rat bone marrow cells and peritoneal macrophages (Kim et al., 2001). It is currently understood that the $\mathrm{P}_{2} \mathrm{X}_{7}$ receptor consists of a homo-oligomer, comprising three or six subunits. To test whether one of the mechanisms underlying the differential effect of polymyxin $\mathrm{B}$ and PMBN on $\mathrm{P}_{2} \mathrm{X}_{7}$ receptor-mediated responses might reside in the different ability of these two antibiotics to affect oligomer formation or stabilization, we analysed $\mathrm{P}_{2} \mathrm{X}_{7}$ receptor subunit aggregation by gel electrophoresis in cell samples treated with ATP or BzATP in the absence or presence of PMB or PMBN. By staining blotted HEK293-hP2X 7 proteins with an anti-P2X receptor polyclonal antibody raised against the carboxyl terminal tail, we identified in quiescent HEK293-hP2X $\mathrm{X}_{7}$ cells three bands of $\mathrm{M}_{\mathrm{r}}$ of about 70, 220 and $440 \mathrm{kDa}$, putatively corresponding to $\mathrm{P}_{2} \mathrm{X}_{7}$ receptor monomer, trimer and hexamer (Figure 6). These bands were absent in wild-type HEK293 cells (WT). Incubation of HEK293-hP2X 7 cells with ATP, BzATP, polymyxin B or PMBN alone had no or little effect on intensity of the three bands. On the contrary, in the presence of polymyxin B and either ATP or BzATP there was a
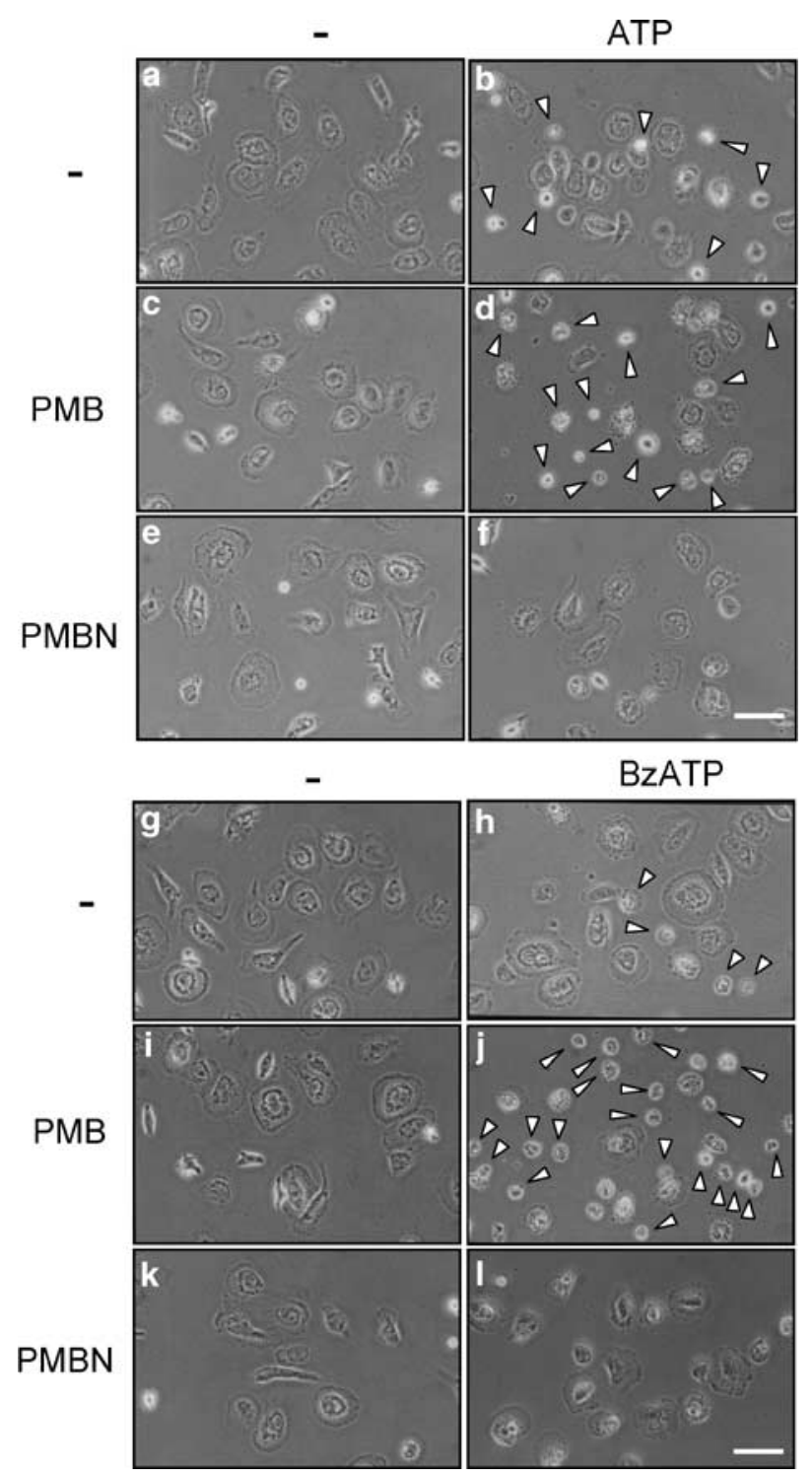

Figure 5 Polymyxin B but not PMBN, induces morphological changes in human macrophages upon stimulation with ATP or BzATP. Cells were obtained as reported in Methods, and incubated for $6 \mathrm{~h}$ at $37^{\circ} \mathrm{C}$, in a standard saline solution, with $10 \mu \mathrm{g} \mathrm{ml}^{-1} \mathrm{PMBN}$ or polymyxin B, in the presence or absence of $1 \mathrm{mM} \mathrm{ATP}$ or $300 \mu \mathrm{M}$ BzATP. Photographs were taken with a $\times 40$ objective; (a) controls; (b) ATP; (c) polymyxin B; (d) polymyxin B +ATP; (e) PMBN; (f) PMBN + ATP; (g) controls; (h) BzATP; (i) polymyxin B; (j) polymyxin B + BzATP; (k) PMBN; (I) PMBN + BzATP. White arrowheads, dead cells. Bars, $50 \mu \mathrm{m}$. A representative experiment is shown, $(n=6)$.

clearcut increase in the 440 band. In the presence of ATP, polymyxin $B$ induced a threefold increase in the optical density of the $440 \mathrm{kDa}$ band (80.6 vs 27.1 densitometric units for ATP + polymyxin B and ATP, respectively). With BzATP as an agonist, the effect of polymyxin $B$ was less pronounced (75.8 vs 49.1 densitometric units for BzATP + polymyxin B and BzATP, respectively), probably because BzATP by itself caused an increased aggregation of the $\mathrm{P}_{2} \mathrm{X}_{7}$ subunits. In several similar immunoblots, polymyxin $\mathrm{B}$ always caused a two- to threefold increase in the density of the $440 \mathrm{kDa}$ band with ATP as an agonist, while the increase was two-fold with BzATP. This suggested to us that a mechanism by which 


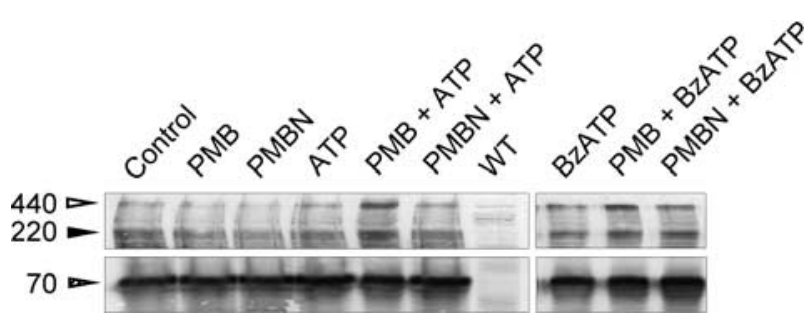

Figure 6 Polymyxin B but not PMBN modulates P2X $\mathrm{X}_{7}$ oligomerization. Western blot analysis was carried out as described in Methods. Cells were preincubated for $15 \mathrm{~min}$ in the presence of polymyxin $B$ or $\mathrm{PMBN}$, then nucleotides were added and incubation carried out over further $30 \mathrm{~min}$. ATP concentration was $1 \mathrm{~mm}$, while BzATP was $100 \mu \mathrm{m}$; wtHEK293 cells were used as a negative control for ${\mathrm{P} 2 \mathrm{X}_{7}}_{7}$ receptor expression. A representative Western blot of three similar is shown.

polymyxin $\mathrm{B}$ might enhance $\mathrm{P} 2 \mathrm{X}_{7}$ receptor-dependent functions is to enhance or stabilize aggregation of the $\mathrm{P}_{2} \mathrm{X}_{7}$ receptor hexamer. In contrast to polymyxin $\mathrm{B}, \mathrm{PMBN}$ had little if any effect on $\mathrm{P}_{2} \mathrm{X}_{7}$ receptor trimer or hexamer assembly.

Polymyxin B but not PMBN induces ATP-dependent cell fusion We previously showed that $\mathrm{P}_{2} \mathrm{X}_{7}$ receptor mediates cell fusion and may participate in the process of macrophagederived multinucleated giant cells formation (Falzoni et al., 1995). We thus tested the effect of polymyxin B and PMBN on $\mathrm{P}_{2} \mathrm{X}_{7}$ receptor-dependent cell fusion. To monitor cell fusion, we initially used HEK293 cells stably expressing a $\mathrm{hP} 2 \mathrm{X}_{7}$ receptor fused with the green fluorescence protein at the $\mathrm{COOH}$ terminus (HEK293-hP2X 7 GFP). Unfortunately, this chimeric receptor $\mathrm{hP} 2 \mathrm{X}_{7} \mathrm{GFP}$ was mostly retained intracellularly with little expression at the membrane surface (not shown). We thus shifted to the rat P2X ${ }_{7} \mathrm{GFP}$ chimera ( $\left.\mathrm{rP}_{2} \mathrm{X}_{7} \mathrm{GFP}\right)$ that was previously shown to have an excellent plasma membrane localization (Morelli et al., 2003). As shown in Figure 7, neither polymyxin B Figure 7e-h nor PMBN Figure 7i-l per se showed any fusogenic activity. Also stimulation with ATP or BzATP had no fusogenic activity (Figures $8 \mathrm{a}-\mathrm{d}$ and $9 \mathrm{a}-\mathrm{d}$ ). However, if either nucleotide was added to polymyxin B-pretreated cells, polykarions were readily formed (Figures $8 \mathrm{e}-\mathrm{h}$ and $9 \mathrm{e}-\mathrm{h}$ ). In contrast to polymyxin B, PMBN did not promote fusion (Figures $8 \mathrm{i}-1$ and 9i-l). While ATP at the concentration used in the experiments shown in Figures 8 and 9 did not promote blebbing (Morelli et al., 2003), BzATP was on the contrary a powerful stimulus for plasma membrane blebbing (Figure 9a-d and i-l). Intriguingly, polymyxin B/BzATP-activated cells that fused to generate the polykarions never showed plasma membrane blebbing (Figure 9e-h), as if fusion and blebbing were two mutually exclusive behaviours.

ATP is a better agonist for $\left[\mathrm{Ca}^{2+}\right]_{\mathrm{i}}$ increase in HEK293-rP2X cells than in HEK293-rP2X 7 GFP cells

The dose-dependency curves for $\left[\mathrm{Ca}^{2+}\right]_{i}$ increases obtained by plotting the $\mathrm{Ca}^{2+}$ increments measured 6 min after ATP addition to the two cell types are shown in Figure 10.

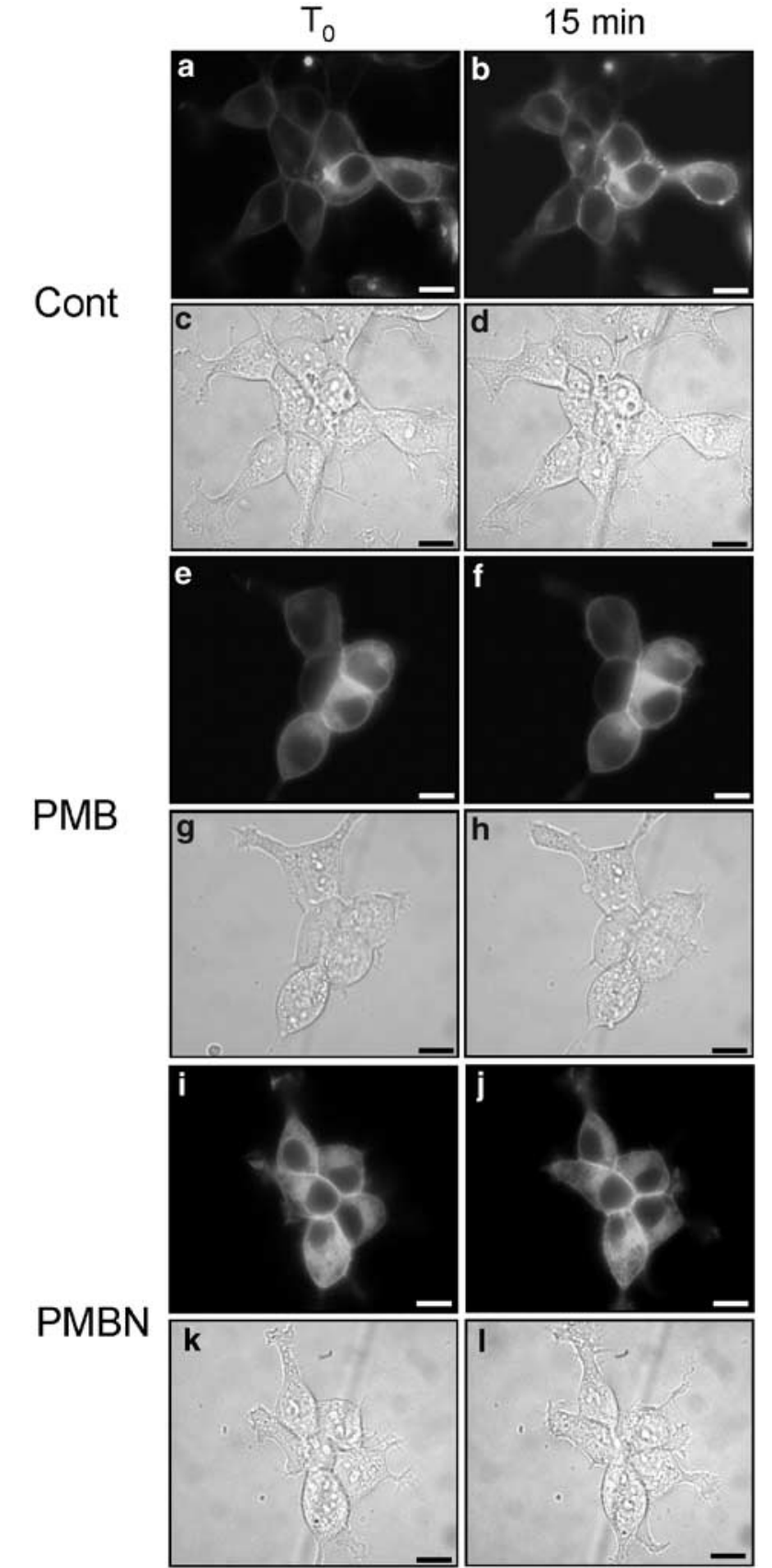

Figure 7 HEK293-rP2X ${ }_{7}$ GFP cells do not form syncythia when incubated with polymyxin B or PMBN. Cells were seeded onto glass coverslips and mounted on the stage of an inverted microscope and monitored as described in Methods. Cells were kept in the presence or absence of polymyxin B or PMBN for 20 min. Controls, (a-d); polymyxin $B,(\mathbf{e}-\mathbf{h})$; PMBN, (i-l). Fluorescence, $(\mathbf{a}, \mathbf{b}, \mathbf{e}, \mathbf{f}, \mathbf{i}, \mathbf{j})$. Phase contrast, (c, d, $\mathbf{g}, \mathbf{h}, \mathbf{k}, \mathbf{I})$. Bars, $10 \mu \mathrm{m}$. A representative experiment is shown $(n=3)$.

Figure 10a shows that, while at low ATP concentrations, the two curves were almost coincident, at high ATP doses ( 1 and $3 \mathrm{~mm}$ ), the $\mathrm{Ca}^{2+}$ response was higher in $\mathrm{rP}_{2} \mathrm{X}_{7^{-}}$, compared to $\mathrm{rP}_{2} \mathrm{X}_{7} \mathrm{GFP}$-expressing cells. The same behaviour was seen with polymyxin $\mathrm{B}$, although in the presence of the antibiotic, $\mathrm{Ca}^{2+}$ increases reached higher values (Figure 10b). 


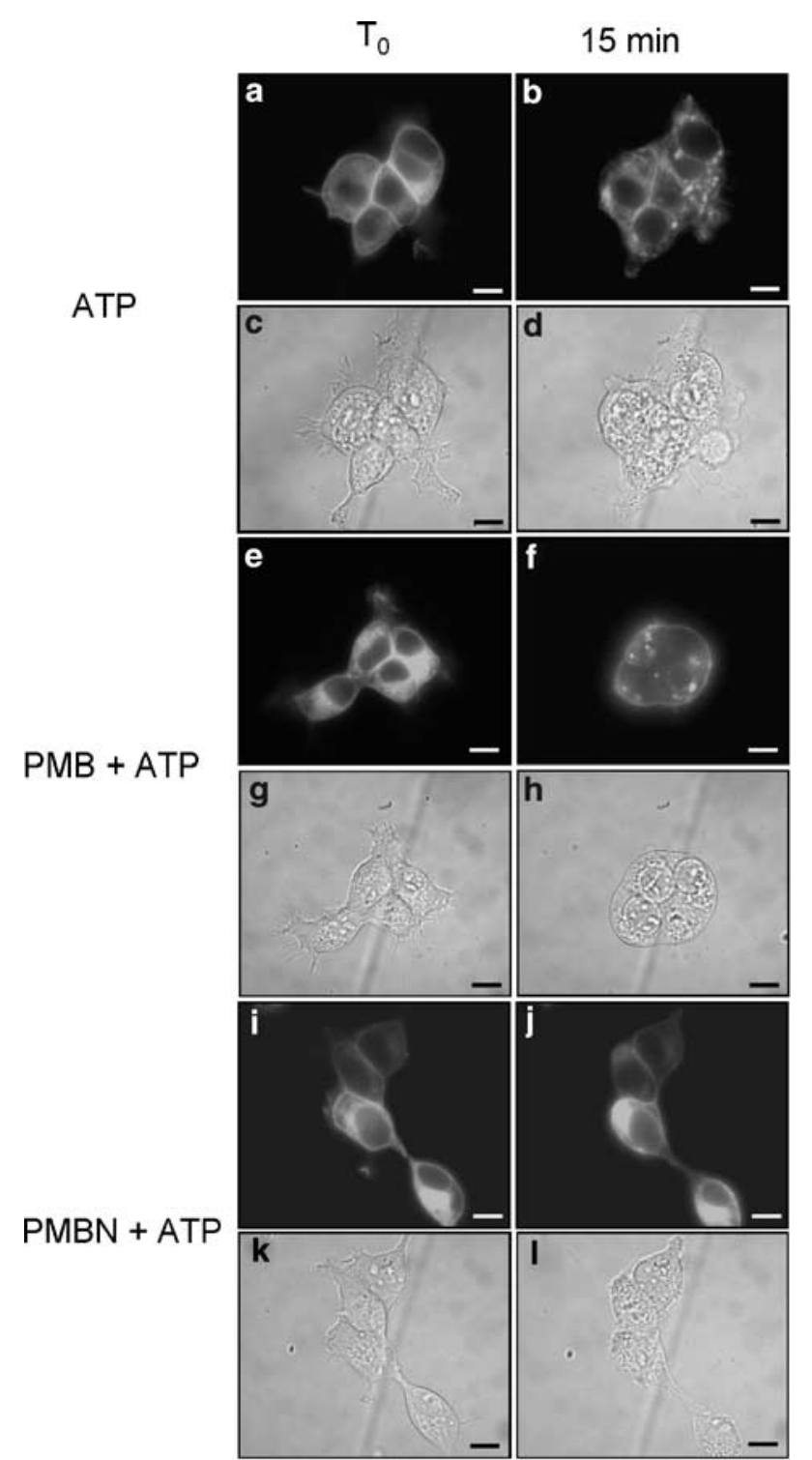

Figure 8 Polymyxin B but not PMBN stimulates cell fusion in the presence of ATP. HEK293-rP2X 7 GFP cells were seeded on glass coverslips and mounted on the stage of an inverted microscope. Cells were preincubated for 5 min with polymyxin B or PMBN and treated with $1 \mathrm{mM}$ ATP for a further $15 \mathrm{~min}$. ATP (a-d); polymyxin B + ATP, (e-h); PMBN + ATP (i-l). Fluorescence $(\mathbf{a}, \mathbf{b}, \mathbf{e}, \mathbf{f}, \mathbf{i}, \mathbf{j})$. Phase contrast $(\mathbf{c}, \mathbf{d}, \mathbf{g}, \mathbf{h}, \mathbf{k}, \mathbf{l})$. Bars, $10 \mu \mathrm{m}$. A representative experiment is shown $(n=3)$.

\section{Discussion}

We recently showed that polymyxin B potentiates ATPand BzATP-stimulated responses in cells bearing the $\mathrm{P}_{2} \mathrm{X}_{7}$ receptor. Upregulation of nucleotide responses by polymyxin B was shown in HEK293 cells transfected with either $\mathrm{hP}_{2} \mathrm{X}_{7}$ or $\mathrm{rP}_{2} \mathrm{X}_{7}$ and in cells expressing the native $\mathrm{P}_{2} \mathrm{X}_{7}$ receptor, such as mouse and human macrophages and human B-cell chronic lymphocytic leukaemia cells. The effect of polymyxin B was fully dependent on $\mathrm{P}_{2} \mathrm{X}_{7}$ receptor expression. No effect was observed on responses mediated by P2Y receptors (Ferrari et al., 2004). Experiments performed

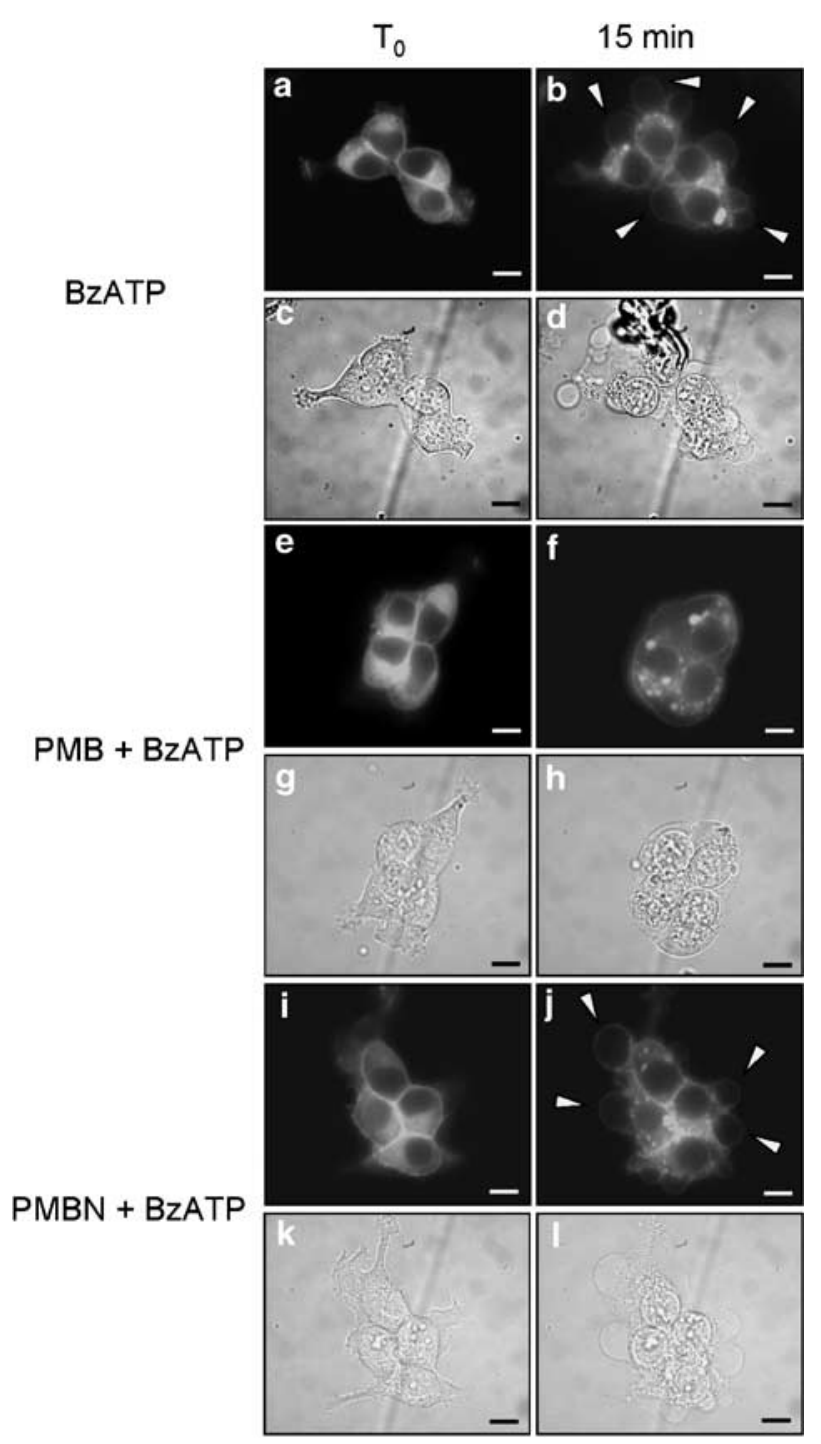

Figure 9 Polymyxin B but not PMBN stimulates cell fusion in the presence of BzATP. HEK293-rP2X 7 GFP were seeded on glass coverslips and mounted on the stage of an inverted microscope. Cells were preincubated for 5 min with polymyxin $\mathrm{B}$ or $\mathrm{PMBN}$ and treated with $300 \mu \mathrm{M}$ BzATP for a further $15 \mathrm{~min}$. BzATP (a-d); polymyxin $\mathbf{B}+\operatorname{BzATP}(\mathbf{e}-\mathbf{h}) ;$ PMBN + BzATP (i-l). Fluorescence $(\mathbf{a}, \mathbf{b}, \mathbf{e}, \mathbf{f}, \mathbf{i}, \mathbf{j})$. Phase contrast $(\mathbf{c}, \mathbf{d}, \mathbf{g}, \mathbf{h}, \mathbf{k}, \mathbf{I})$. Bars, $10 \mu \mathrm{m}$. A representative experiment is shown $(n=3)$.

with the mutant $\mathrm{rP}_{2} \mathrm{X}_{7}$ receptor with deletion of the last 179 carboxy-terminal amino-acid residues showed that polymyxin B retained its enhancing activity in cells transfected with this mutant $\mathrm{P}_{2} \mathrm{X}_{7}$ receptor, thus indicating that the binding site must be located in the short $\mathrm{N}$-terminal domain, in the two transmembrane stretches or in the bulky extracellular domain. Given the lipophilicity of polymyxin $\mathrm{B}$, it is likely that the binding site might reside in a hydrophobic domain of the $\mathrm{P}_{2} \mathrm{X}_{7}$ receptor molecule.

Polymyxin B has two hydrophobic regions, the $N$-terminal fatty acid moiety and a D-Phe ${ }^{5}-$ Leu $^{6}$ segment in the peptide ring (Tsubery et al., 2002). Previous data showed that PMBN, which lacks the $N$-terminal fatty acid moiety, has a drastically reduced bactericidal activity (Tsubery et al., 2001), 

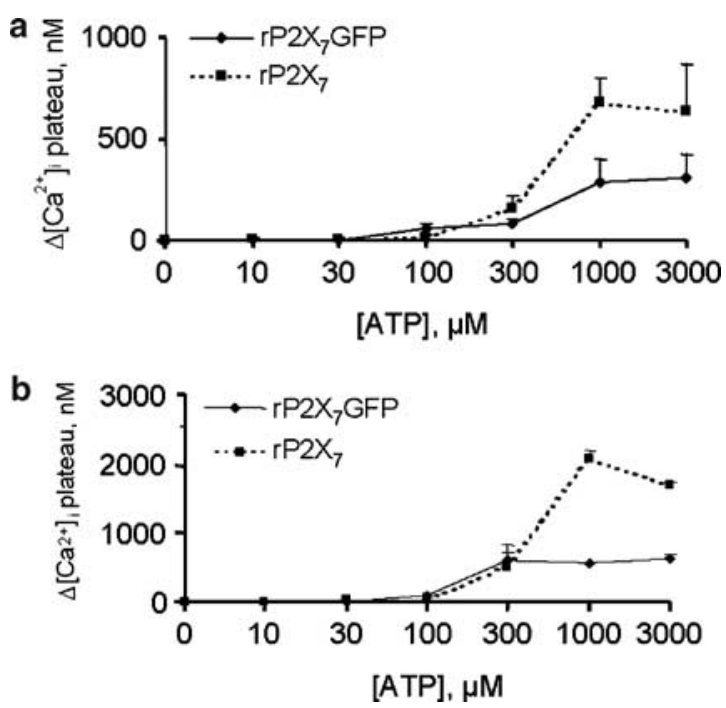

Figure 10 Dose-response curves for ATP-induced increase of $\left[\mathrm{Ca}^{2+}\right]_{i}$ in HEK293-rP2X 7 and HEK293-rP2X 7 GFP cells in the presence or absence of polymyxin $B$. Cells $\left(1 \times 10^{6} \mathrm{ml}^{-1}\right)$ were loaded with the fluorescent dye fura-2/AM as reported in Methods and incubated at $37^{\circ} \mathrm{C}$ in standard saline solution in the presence of increasing ATP concentrations. (a), controls; (b), polymyxin B. HEK293-rP2X 7 cells, dashed line; HEK293-rP2X 7 GFP cells, continuous line. Data are means \pm s.d. from triplicate determinations.

but its pore-forming ability is not substantially reduced (Tsubery et al., 2001). We show here that ability of PMBN to interact with the $\mathrm{P} 2 \mathrm{X}_{7}$ receptor is severely impaired, in an agonist-dependent fashion. With ATP as an agonist PMBN was unable to potentiate $\mathrm{P}_{2} \mathrm{X}_{7}$ receptor-dependent responses, while it was able to potentiate BzATP-stimulated responses, albeit to a much lesser extent compared to polymyxin B. Furthermore, PMBN, in contrast to polymyxin $\mathrm{B}$, did not reverse $\mathrm{P}_{2} \mathrm{X}_{7}$ receptor inhibition due to $\mathrm{KN}-62$. These data indicate that a hydrophobic interaction is critical for polymyxin B-dependent potentiation of $\mathrm{P} 2 \mathrm{X}_{7}$ receptor responses. The experiments also provide hints as to the mechanism by which polymyxin $B$ potentiated $\mathrm{P}_{2} \mathrm{X}_{7}$ receptor responses. We previously showed that polymyxin $\mathrm{B}$ by itself was unable to activate the $\mathrm{P}_{2} \mathrm{X}_{7}$ receptor even at very high doses, but shifted ATP or BzATP dose-response curves to the left and potentiated both the channel and the pore functions of this receptor. This suggested to us that polymyxin B might work as an allosteric modulator of the receptor.

Positive or negative allosteric modulators are receiving increasing attention as drugs that may allow a better tuning of cell receptors in comparison to well-known receptor agonists and antagonists. This might be of relevance for the $\mathrm{P}_{2} \mathrm{X}_{7}$ receptor whose effects on cell physiology differ dramatically depending on the two different states of activation, the channel and the pore. For example, it would be of great help to identify pharmacological agents that may enhance the channel but not the pore function, or vice versa. This might help dissociate beneficial from detrimental effects due to $\mathrm{P}_{2} \mathrm{X}_{7}$ receptor stimulation, or modulate the pore function, controlling its opening in a way that prevents the irreversible effects due to its uncontrolled activation. An example of this is the fusogenic activity of polymyxin B in the $\mathrm{rP}_{2} \mathrm{X}_{7} \mathrm{GFP}$ cells. Modulation of pore opening by polymyxin $\mathrm{B}$ generated the right local conditions to support fusion. It is not at all clear how $\mathrm{P}_{2} \mathrm{X}_{7}$ receptor supports fusion. In previous work, we postulated that pore formation on the cell membrane of adjacent cells might contribute to establish an early cell-to-cell communication that eventually would facilitate formation of cytoplasmic bridges and membrane fusion (Falzoni et al., 2000). The fusogenic activity of the $\mathrm{P}_{2} \mathrm{X}_{7}$ receptor is strongly dependent on the level of receptor activation in that while low-level, tonic stimulation promotes fusion, sustained activation as it occurs in the presence of exogenously added ATP or BzATP, triggers cell changes (i.e. rounding, swelling) that eventually prevent fusion. Thus we were surprised by the occurrence of cell fusion in HEK293 cells stably expressing the rat $\mathrm{P}_{2} \mathrm{X}_{7}$ receptor (HEK293-rP2X ${ }_{7}$ GFP cultures. Appending the GFP residue to the $\mathrm{P} 2 \mathrm{X}_{7}$ receptor is known to decrease ATP affinity (Smart et al., 2002). Thus, we hypothesize that the fusogenic effect observed is due to a more tightly controlled activation of the $\mathrm{P} 2 \mathrm{X}_{7}$ receptor under these conditions.

Polymyxin B might facilitate fusion in different ways. Thanks to its amphipathic structure it might bring cells into a closer contact that might maximize the likelihood that pore opening on one cell occurs in close proximity to another, and thus might result more easily in fusion. Alternatively, polymyxin B might affect recruitment of $\mathrm{P}_{2} \mathrm{X}_{7}$-interacting proteins that participate in cell fusion. Polymyxin $\mathrm{B}$ might also increase $\mathrm{P}_{2} \mathrm{X}_{7}$ receptor stability in the plasma membrane, or favour subunit aggregation into an oligomeric fusogenic structure. Although an in depth characterization of this phenomenon goes beyond the aims of the present work, the observation that hexamer formation is increased in the presence of polymyxin B points in this direction.

Although the $\mathrm{P} 2 \mathrm{X}_{7}$ receptor meets with increasing interest for its intriguing functional properties and the exciting potential pharmacological applications, full appreciation of its properties has been hampered by lack of suitable agonists or antagonists. We have proposed an alternative approach based on the search of positive or negative effectors (allosteric modulators) that may help to fine tune $\mathrm{P}_{2} \mathrm{X}_{7}$ receptor activation (Sanz et al., 1998). The rationale was that the combined administration of ATP plus any of these compounds might have advantages over the administration of ATP alone. For example, in an hypothetical therapeutical protocol aimed at enhancing $\mathrm{P}_{2} \mathrm{X}_{7}$ receptor-dependent responses, it might be useful to administer ATP together with polymyxin $\mathrm{B}$, because this would allow a reduction in the concentration of ATP and thus reduce the possible side effects due to ATP breakdown products, such as adenosine). Along the same lines, by carefully using allosteric modulators of the $\mathrm{P}_{2} \mathrm{X}_{7}$ receptor it might be possible to enhance, selectively, the channel rather than the pore function or vice versa. Thus in principle it would be possible to take advantage of the beneficial and to suppress the detrimental effects of $\mathrm{P}_{2} \mathrm{X}_{7}$ receptor activation (Ferrari et al., 1994). It is likely that such a fine tuning of $\mathrm{P}^{2} \mathrm{X}_{7}$ receptor opening also occurs in vivo as in some tissues there is clear demonstration that although a full-length and functional $\mathrm{P}_{2} \mathrm{X}_{7}$ receptor is 
expressed, the typical $\mathrm{P}_{2} \mathrm{X}_{7}$ receptor pore never forms, even upon sustained activation. Even in the very same tissue, functionally different cells (i.e. acinar vs ductal cells in the parotid) may express $\mathrm{P}_{2} \mathrm{X}_{7}$ receptor with widely different electrophysiological properties (Li et al., 2003).

These data indicate that the native $\mathrm{P}_{2} \mathrm{X}_{7}$ receptor is regulated in a much more sophisticated fashion than we currently think, and that the best hope for therapeutic development of this receptor rests on the design and synthesis of positive or negative modulators of its function.

\section{Acknowledgements}

This work was supported by grants by the Italian Ministry of Education, University and Scientific Research (MIUR), the National Research Council of Italy, the Italian Association for Cancer Research (AIRC), the Italian Space Agency (ASI), Telethon of Italy and by local funds from the University of Ferrara.

\section{Conflict of Interest}

The authors state no conflict of interest.

\section{References}

Burnstock G (2004). Introduction: P2 receptors. Curr Top Med Chem 4: 793-803.

Cabrini G, Falzoni S, Forchap SL, Pellegatti P, Balboni A, Agostani P et al. (2005). A His-155 to Tyr polymorphism confers gain-offunction to the human $\mathrm{P}_{2} \mathrm{X}_{7}$ receptor of human leukemic lymphocytes. J Immunol 175: 82-89.

Daugelavicius R, Bakiene E, Bamford DH (2000). Stages of polymyxin $\mathrm{B}$ interaction with the Escherichia coli cell envelope. Antimicrob Agents Chemother 44: 2969-2978.

Di Virgilio F, Chiozzi P, Falzoni S, Ferrari D, Sanz J, Venketaraman V et al. (1998). Cytolytic P2X purinoceptors. Cell Death Diff 5: 191-199.

Di Virgilio F, Chiozzi P, Ferrari D, Falzoni S, Sanz JM, Morelli A et al. (2001). Nucleotide receptors: an emerging family of regulatory molecules in blood cells. Blood 97: 587-600.

Dubyak GR, El-moatassim C (1993). Signal transduction via P2purinergic receptors for extracellular ATP and other nucleotides. Am J Physiol 265: C577-C606.

Duwe AK, Rupar CA, Horsman GB, Vas SI (1986). In vitro cytotoxicity and antibiotic activity of polymyxin B nonapeptide. Antimicrob Agents Chemother 30: 340-341.

Evans ME, Feola DJ, Rapp RP (1999). Polymyxin B sulfate and colistin: old antibiotics for emerging multiresistant gram-negative bacteria. Ann Pharmacother 33: 960-967.

Falzoni S, Chiozzi P, Ferrari D, Buell G, Di Virgilio F (2000). P2X receptor and polykarion formation. Mol Biol Cell 11: 3169-3176.

Falzoni S, Munerati M, Ferrari D, Spisani S, Moretti S, Di Virgilio F (1995). The purinergic P2Z receptor of human macrophage cells. Characterization and possible physiological role. J Clin Invest 95: 1207-1216.

Ferrari D, La Sala A, Chiozzi P, Morelli A, Falzoni S, Girolomoni G et al. (2000). The P2 purinergic receptors of human dendritic cells: identification and coupling to cytokine release. FASEB J 14: 2466-2476.

Ferrari D, Munerati M, Melchiorri L, Hanau S, Di Virgilio F, Baricordi OR (1994). Responses to extracellular ATP of lymphoblastoid cell lines from Duchenne muscular dystrophy patients. Am J Physiol 267: C886-C892.

Ferrari D, Pizzirani C, Adinolfi E, Forchap S, Sitta B, Turchet L et al. (2004). The antibiotic polymyxin $\mathrm{B}$ modulates $\mathrm{P}_{2} \mathrm{X}_{7}$ receptor function. J Immunol 173: 4652-4660.

Fredholm BB, Abbracchio MP, Burnstock G, Dubyak GR, Harden TK, Jacobson A et al. (1997). Towards a revised nomenclature for P1 and P2 receptors. Trends Pharmacol Sci 18: 79-82.

Gu BJ, Zhang W, Worthington RA, Sluyter R, Dao-Ung P, Petrou S et al. (2001). A Glu-496 to Ala polymorphism leads to loss of function of the human ${\mathrm{P} 2 \mathrm{X}_{7}}_{7}$ receptor. I Biol Chem 276: $11135-11142$.

Hancock RE (2001). Cationic peptides: effectors in innate immunity and novel antimicrobials. Lancet Infect Dis 1: 156-164.

Jacobson KA, Jarvis MF, Williams M (2002). Purine and pyrimidine (P2) receptors as drug targets. J Med Chem 45: 4057-4093.

Kim M, Spelta V, Sim J, North RA, Surprenant A (2001). Differential assembly of rat purinergic $\mathrm{P}_{2} \mathrm{X}_{7}$ receptor in immune cells of the brain and periphery. J Biol Chem 276: 23262-23267.

Li Q, Luo X, Zeng W, Muallem S (2003). Cell-specific behaviour of $\mathrm{P}_{2} \mathrm{X}_{7}$ receptors in mouse parotid acinar and duct cells. J Biol Chem 278: 47554-47561.

Marshall JD, Higgins D, Abbate C, Yee P, Teshima G, Ott G et al. (2004). Polymyxin B enhances ISS-mediated immune responses across multiple species. Cell Immunol 229: 93-105.

Morelli A, Chiozzi P, Chiesa A, Ferrari D, Sanz JM, Falzoni S et al. (2003). Extracellular ATP causes ROCK I-dependent bleb formation in $\mathrm{P}_{2} \mathrm{X}_{7}$-transfected HEK293 cells. Mol Biol Cell 14: $2655-2664$.

North RA (2002). Molecular physiology of P2X receptors. Physiol Rev 82: 1013-1067.

Sanz JM, Chiozzi P, Di Virgilio F (1998). Tenidap enhances P2Z/P2X receptor signalling in macrophages. Eur J Pharmacol 355: 235-244.

Smart ML, Panchal RG, Bowser DN, Williams DA, Petrou S (2002). Pore formation is not associated with macroscopic redistribution of $\mathrm{P} 2 \mathrm{X}_{7}$ receptors. Am J Physiol Cell Physiol 283: C77-C84.

Steinberg TH, Newman AS, Swanson JA, Silverstein SC (1987). ATP ${ }^{4}$ permeabilizes the plasma membrane of mouse macrophages to fluorescent dyes. J Biol Chem 262: 8884-8888.

Storm DR, Rosenthal KS, Swanson PE (1977). Polymyxin and related peptide antibiotics. Annu Rev Biochem 46: 723-763.

Tatham PE, Lindau M (1990). ATP-induced pore formation in the plasma membrane of rat peritoneal mast cells. J Gen Physiol 95 459-476.

Tsubery H, Ofek I, Cohen S, Eisenstein M, Fridkin M (2002). Modulation of the hydrophobic domain of polymyxin B nonapeptide: effect on outer-membrane permeabilization and lipopolysaccharide neutralization. Mol Pharmacol 62: 1036-1042.

Tsubery H, Ofek I, Cohen S, Fridkin M (2000). The functional association of polymyxin $B$ with bacterial lipopolysaccharide is stereospecific: studies on polymyxin B nonapeptide. Biochemistry 39: 11837-11840.

Tsubery H, Ofek I, Cohen S, Fridkin M (2001). N-terminal modifications of Polymyxin B nonapeptide and their effect on antibacterial activity. Peptides 22: 1675-1681.

Vaara M, Viljanen P (1985). Binding of polymyxin B nonapeptide to gram-negative bacteria. Antimicrob Agents Chemother 27: 548-554.

Valentinis B, Bianchi A, Zhou D, Cipponi A, Catalanotti F, Russo V et al. (2005). Direct effects of polymyxin B on human dendritic cells maturation@ The role of IkappaB-alpha/NF-kappaB and ERK1/2 pathways and adhesion. J Biol Chem 280: 14264-14271.

Von Kugelgen I, Wetter A (2000). Molecular pharmacology of P2Yreceptors. Naunyn Schmiedebergs Arch Pharmacol 362: 310-323. 